\title{
Reducing plastic waste for the competitiveness of Vietnamese tourist attractions
}

\author{
Minh Tuan Tran ${ }^{1 *}$, Trung Luong Pham ${ }^{2}$, and Xuan Tung Nguyen ${ }^{3}$ \\ ${ }^{1}$ Graduate Academy of Social Sciences, 477 Nguyen Trai, Thanh Xuan, Hanoi, 100000, Vietnam \\ ${ }^{2}$ Institute of Environment \& Sustainable Development, E Building, No.6, Dang Van Ngu, Dong Da, \\ Hanoi, 100000, Vietnam \\ ${ }^{3}$ Institute of Southeast Asian Studies, No.1, Lieu Giai, Ba Dinh, Hanoi, 100000, Vietnam
}

\begin{abstract}
Plastic usage in tourism activities has increased significantly in Vietnam over the past decades, leading to the burden of plastic pollution and the threat to sustainable tourism development. The Vietnamese government has recognized the importance of plastic waste management in sustainable tourism. Laws and regulations on controlling pollution due to non-biodegradable plastic bags. Public education activities have been organized to encourage people replace plastic products with natural materials, reuse plastic bags and reduce plastic wastes. Many tourism businesses have found ways to limit plastic consumption, such as replacing disposal plastic products with eco-friendly products. Vietnamese tourism has taken the first steps in reducing plastic waste pollution in tourism activities. This article proposed some solutions to limit and restrain plastic wastes from tourism in Vietnam.
\end{abstract}

\section{Introduction}

Man-made plastic was created by Alexander Parkes, an English scientist from Birmingham in 1855 , yet only until 1909 were plastic products based on synthetic polymer invented by Leo Hendrik Baekeland, a Belgian-born American scientist in New York. Nylon products were first introduced by DuPont in the 1939 New York World's Fair and soon became popular in a global scale because of its versatility and low cost.

Plastic is present in everyday life; it is also an important material in many industries such as electricity, electronics, telecommunications, transportation, fisheries, agriculture, etc. Thanks to the development of science and technology, plastic has (have) become a substitute for traditional material which were previously considered irreplaceable such as wood, metal, silicate, etc. The plastic industry is playing an increasingly vital role in many nations. Along with the development of plastic industry and the use of plastic products, plastic waste is also an integral part of human life on Earth.

\footnotetext{
*Corresponding author: minhtuanvass@gmail.com
} 


\section{Theoretical frameworks}

\subsection{Definition}

Whether from a social or individual perspective, wastes are things that living bodies exert into the environment. Wastes can also be materials or items discharged into nature when they are no longer of use or of value in production, processing, trading or services.

Of course, trash of one person is treasure to another, so "end of use value" is a relative idea. Reused waste is no longer waste. Ultimately, waste should be understood as pollutants, non-reusable things.

Waste can be divided into: solid waste (garbage) and liquid waste; hazardous waste and non-hazardous waste; biodegradable wastes and non-biodegradable wastes which can exist in nature for hundreds of years. Waste can also be classified by origin: domestic and service waste, industrial waste, construction waste, medical waste, etc.

Plastic waste is a form of solid non-degradable waste. As such, it contains high risks for pollution, affecting ecosystems and the lives of many species in the wild. According to scientists, it requires at least 100 years for plastic bag and 200 years for plastic bottles to decompose [1]. This means that the existence of plastic waste will negatively affect the nature environment - the foundation of tourism. In many coastal resorts, marine protected areas, even key tourist areas, plastic wastes affect not only marine landscape but also affect marine tourism resources such as the quality of sea water and the existence of marine species and ecosystems.

On a global scale, while plastic consumption increases, only $14 \%$ of plastic packaging is collected and recycled, significantly lower than paper (58\%) and iron (90\%) [2]. Ninetyfive percent of plastic packaging is lost, equivalent to 80 to 120 billion USD per year. According to UN report, the global plastic disposal every year is 4 times the length of the earth [3]. 1,000 plastic bags are produced every minute but only $27 \%$ of them are processed and recycled. In 2012, Europe produced about 25.2 million tons of plastic waste, but only about $26 \%$ of them was collected for recycling. The remaining $74 \%$ is burned for energy or buried. The consequence is an increase in plastic waste in soil and ocean environments.

\subsection{Threats of plastic wastes}

According to the Wall Street Journal, in 2010, one third of the global plastic waste discharged into the sea comes from China and Indonesia [4]. Every year, China disposes 8.8 million tons of plastic wastes into the sea; while Indonesia disposes 3.2 million tons illegally. Philippines ranked 3rd with 1.9 million tons and Vietnam ranked 4th with 1.8 million tons.

Ocean Conservancy's report in 2017 found that the total plastic wastes of 5 Asian countries (China, Indonesia, Philippines, Thailand and Vietnam) disposed to the sea is more than the plastic waste of all other countries in the world combined [5].

Professor Carmen Ablan Lagman at De La Salle University (Philippines) believed that the biggest threat of plastic waste comes from micro-plastics - plastic particles smaller than $5 \mathrm{~mm}$ and undetectable by human eyes [6]. Micro-plastic is a common component in cosmetics, artificial detergents, and chemicals such as acrylic, melamine used in industry. The secondary source of micro plastic emission is disposable plastic products such as plastic bags, plastic pet bottles, disposable straws, etc.

According to Nguyen Chu Hoi, the East Sea is one of the marine regions with the largest amount of plastic wastes in the world [7]. Under the impact of the ocean circulations, plastic wastes in the East Sea becomes a serious trans-national issue, posing significant threats to coastal areas in the region, especially when China and Indonesia are 
countries with the largest amount of plastic waste.

Plastic wastes have become a global environmental threat. It is expected that millions of USD are required every year to clean areas contaminated by plastic wastes [8]. This reduces revenue from land-related economic activities, especially tourism. In this context, Vietnam is working with international communities to limit and eventually eliminate plastic pollution.

\section{Discussion}

Plastic wastes are detrimental to the ecosystem and the life of many species in nature. In many tourist attractions or even marine conservations in the world, plastic wastes affect not only the natural landscape but also water quality, the ecosystem and the survival of species which are considered key tourism resources.

While the amount of plastic in everyday uses as well as in tourism activities increases, a very small percentage of plastic packaging is processed and recycled. This becomes a threat to the environment, especially tourism environment. The threat of plastic wastes to the environment is a global problem, influencing the socio-economic development of any country. As such, the global community is taking serious effort to limit and restrain plastic pollution.

Research on plastic wastes found that the majority of plastic wastes in Vietnam comes from domestic sources. The rate of domestic plastic wastes in urban area is $70-90 \%$ [9]. The amount of plastic wastes in the urban area is also significantly higher than in rural area, with $0.42 \mathrm{~kg} /$ person/day compared to $0.33 \mathrm{~kg} /$ person/day.

Table 1. Estimation of domestic plastic wastes in Vietnam by years

\begin{tabular}{lll}
\hline Year & Population (million) & Domestic plastic wastes (tons/day) \\
\hline 2015 & 93.17 & 33261,600 \\
2016 & 93.82 & $33,493,649$ \\
2017 & 94.49 & $33,732,838$ \\
2018 & 95.26 & $34,007,727$ \\
2019 & 96.02 & $34,343,400$ \\
\hline
\end{tabular}

Another notable source of plastic wastes is from tourism. As the number of tourists keeps increasing, each tourist disposes an average of $0.65 \mathrm{~kg} /$ day [10]. This amount is even higher higher than domestic plastic waste, creating a burden for plastic waste management system, especially in urban cities like Hanoi, Ho Chi Minh city, Ha Long, Hue, Da Nang, Nha Trang, etc.

Table 2. Plastic wastes from tourism activities

\begin{tabular}{lllll}
\hline Year & \multicolumn{2}{l}{ Number of tourists (thousands) } & $\begin{array}{l}\text { Domestic plastic } \\
\text { wastes (tons/day) }\end{array}$ & $\begin{array}{l}\text { Average duration of stay } \\
\text { (days) }\end{array}$ \\
\cline { 2 - 5 } & International & Local & $10,858,000$ & $\begin{array}{l}\text { - International tourists }: 3.0 \\
\text { - Local tourists }: 1.8\end{array}$ \\
\hline 2015 & 7,944 & 57,000 & $12,519,000$ & $\begin{array}{l}\text { - International tourists }: 3.2 \\
\text { - Local tourists }: 1.7\end{array}$ \\
2016 & 10,013 & 62,000 & $15,162,000$ & $\begin{array}{l}\text { - International tourists }: 3.1 \\
\text { - Local tourists }: 1.7\end{array}$ \\
2017 & 12,922 & 73,000 & $17,692,000$ & $\begin{array}{l}\text { - International tourists }: 3.4 \\
\text { - Local tourists }: 1.6\end{array}$ \\
2018 & 15,498 & 80,000 & & - International tourists $: 3.5$ \\
2019 & 18,020 & 85,000 & $21,163,000$ & \\
\hline
\end{tabular}


The ability to collect and process wastes in all over Vietnam remains limited, with an average of $85.5 \%$ in urban areas [9]. A great amount of plastic wastes from domestic and tourism sources remained unprocessed, causing environmental pollution.

\subsection{Plastic wastes from tourism in Vietnam}

In Vietnam, despite being a young industry compared to other long-standing industries such as mechanics, electricity - electronics, chemicals, textiles, etc., the plastic industry has experienced speedy development in recent years here. The plastic industry is one of the industries with the highest growth rate in Vietnam in the 2010-2015 period, with an average increase of $16 \%$ - 18\% per year, standing right after telecommunications and textile industry [11]. Because the starting point of Vietnam's plastic industry is still low compared to the world and thanks to its large market, plastic products are widely used in all areas of life including plastic packaging products, plastic construction materials, household plastic products and high-tech plastic products. In 2015, Vietnam produced and consumed about 5 million tons of plastic, $80 \%$ of which used imported plastic scraps [11]. Plastic consumption index per capita in Vietnam increased rapidly from $3.8 \mathrm{~kg} /$ year in 1990 to $41 \mathrm{kgs} /$ year in 2015.

In the tourism sector in Vietnam, since 2010, the demand for plastic products has increased with the same speed of tourism development. Plastic products are used in almost all services provided to tourists, especially in the form of product packaging such as water bottles, fast food packages, food carriers, etc. In addition, plastic products such as glassbottom boats, speedboats, entertainment devices, hotel furniture, etc. are also quite popular. The demand of plastic products leads to fast increase in plastic wastes.

In 2018, Vietnamese tourism serves more than 80 million domestic visitors with the average length of stay was 1.8 days, and over 15 million international tourists with average length of stay was 3.5 days [12]. The total number of visitors in 2018 in Vietnam was nearly 200 million visitors. If on average, each tourist uses at least 01 bottle of water and 01 plastic bag per day to pack goods (i.e. souvenirs, snacks), the minimum amount of plastic waste consumed by the service industry in 2018 was 200 million plastic bottles and plastic bags. That is not to mention plastic wastes from other services provided to customers such as refreshment (plastic cups, plastic straws), catering (foam boxes), daily hotel supplies and chemical cleaning products used in accommodation facilities, etc.

The 2017 Travel and Tourism Competitiveness report shows that, while Vietnam's natural and cultural attractions ranked 30 and 34 in the world, Vietnam's environmental sustainability index ranked 129 out of 136 countries. Vietnam scored very low on waste treatment with a score from 0.1 to 0.2 out of 7.0 [13].

The Food and Agriculture Organization (FAO) reported that in 2018, Vietnam has discharged more than 1.8 million tons of unprocessed plastic wastes, accounting for nearly $6 \%$ of plastic wastes in the world [12]. Vietnam ranked fourth in the world for plastic waste disposal to the sea in 2018 , with 0.28 to 0.73 million tons, making pollution an increasingly urgent issue.

Plastic wastes have significantly affected the image of many key tourist destinations in Vietnam such as Ha Long Bay, Cam Ranh Bay, Phan Thiet - Mui Ne, etc. [14]. In other words, the habit of using plastic products in tourism services has become a burden for the national goal of reducing plastic wastes.

The Vietnamese government has since long recognized the importance of environmental protection and in particular, plastic waste management, to sustainable tourism. Vietnam Prime minister issued the National strategy on solid waste management 
in 2009, which was later revised in 2018. The National project on increased control of environmental pollution due to non-biodegradable plastic bags was passed in 2013. The Vietnam Congress has issued the Law for Environmental protection tax and related documents, including considering environmental unfriendly plastic bag is subjected to environmental protection tax.

Some organizations have organized events to educate the consequences of nondegradable plastic bags, encourage reuse of plastic bags and degradable bags, and launch campaigns against plastic wastes in order to raise public awareness of plastic waste management. Having studied the current situation of waste generation and management, WWF and experts have instructed local authorities to identify suitable policies and educational programs on plastic waste management in accordance with local regulations and supporting resources [15].

Many travel businesses have tried to reduce plastic pollution. Instead of distributing plastic water bottles to customers, some companies have provided big-sized water bottles and requested customers to reuse their personal bottles. Conference sites and hotels also switch to glass bottles and cups for multiple uses. Plastic goods are gradually replaced by natural products such as bamboo straws, cups, etc. Many hotels are requiring suppliers to reduce plastic packaging such as one-layer nylon bag for toilet paper while encouraging their staff to classify trash. Some tourism businesses also organize garbage collection tours in Nha Trang, Hoi An, etc. or ask guests to bring their trash back after trekking trips. However, these are only a few sparks in the general picture of environmental protection in tourism; yet plastic waste management remains limited.

\subsection{Main problems in plastic waste management in Vietnamese tourism}

i) Limited awareness of the impact of plastic wastes on the environment and the habit of using plastic products in tourism and service provision, as well as visitors' habits of waste disposal in tourist attractions.

ii) Lack of policies to encourage eco-friendly products and materials and policies to restrict the use of plastic products in tourism. For example, in 2012, the Ministry of Culture, Sports and Tourism issued the Blue Lotus set of criteria for sustainable tourism applied to tourist accommodations in Vietnam. Of 81 criteria, only 3 criteria are related to plastic waste management, including: "Purchasing packaged products in large quantities to reduce packaging and reduce waste" (D1.1); "Waste classification: recyclables for sale, organic waste for livestock or compost, and hazardous waste for separate disposal" (D2.12) and "Reuse containers of shampoo, conditioner, shower gel and soap" (D2.13).

iii) Lack of punishment for inappropriate plastic usage and plastic waste disposal behaviors of tourists.

iv)Restricted capacity in environmental management in general and plastic waste management in particular in the tourism sector.

v) Restrictions in transboundary, trans-regional management of plastic waste towards sustainable tourism.

\section{Conclusions}

Having recognized fundamental issues of plastic wastes and the situation of plastic waste management in tourism to improve competitiveness of tourist attraction spots in Vietnam recent years, we proposed a number of solutions to limit plastic wastes in tourism towards sustainable development.

Firstly, it is necessary to identify the serious threats of plastic wastes to the tourism environment, business performance and tourists' satisfaction. Through various forms, 
including smartphone applications, promote social awareness of plastic smart consumption, especially among tourists and tourism businesses. Encourage social enterprises to collect wastes in tourist sites, aiming to build "green tourist destinations" - no trash, no plastic bags and disposable plastic products.

Secondly, assure strict adherence to environmental protection laws in tourism, especially Environmental Protection Law in 2018, Tourism Law in 2017, Law on Biological diversity in 2008, etc. Waste management (including plastic wastes) is clearly specified in the Government's Decree No. 38/2015-ND/CP on waste and scrap management, Circular No. 36/2015-TT/BTNMT of Ministry of Natural Resources and Environment on hazardous waste management, etc.

With regard to plastic waste management in tourism, the government has issued Directive no. 18/CT-TTg on September 4, 2013 on strengthening the management of tourism environment, ensuring security and safety for tourists; Decision no. 582/QD-TTg dated September 4, 2013 to approve the Project: "Enhancing the control of environmental pollution due to non-degradable nylon bags in daily uses until 2020"; and Decision no. 1857/BVHTTDL-TCDL on environmental protection, restricting the use of plastic bags, plastic straws and disposable plastic cups. A review of the implementation of these regulations is necessary to evaluate the effectiveness of plastic waste management policies.

Thirdly, the Vietnam National Administration of Tourism should review policies encouraging eco-friendly products and restricting the use of plastic products in tourism. Propose policy advices and adjustments towards encouraging environmental friendly products and materials; increased punishment for violations of plastic waste disposal in tourism development activities.

Fourthly, adjust the Blue Lotus set of criteria for sustainable tourism applied to tourist accommodations in Vietnam to further reduce plastic wastes; promote "Green Tourism Label" which covers criteria for plastic use and plastic waste management.

Fifthly, strengthen the environmental management capacity of state agencies through restructuring, organizing professional training on tourism environment, promoting coordination with tourism sites to reduce plastic consumption.

Sixthly, enhance the role of Tourism Associations in environmental protection activities to reduce plastic wastes, such as the "Tourists helps protect the environment and limit plastic waste" program.

Seventhly, each organization and individual should have specific actions to reduce plastic wastes, including:

- Increase using environmental friendly products such as straws, cups, etc. made of organic materials or reusable products; prioritize buying products with eco-friendly labeling, products that use organic, easily biodegradable, and reusable packaging;

- Reduce or stop using water in pre-packed plastic bottles. Travel businesses set up plans to replace individual water bottles provided during tours with big-sized water bottles and collect tourists' water bottles for reuse;

- Restrict or stop using disposable plastic products such as plastic straws, spoons, plates, bowls, cups in catering services at hotels, restaurants, entertainment sites, etc.

- Reduce chemical cleaning substances and encourage eco-friendly cleaning products at hotels, restaurants, bar, etc.

Protecting the tourism environment and reducing the impacts of plastic wastes towards sustainable tourism require public involvement and leading efforts of the tourism industry and related stakeholders. 


\section{References}

1. T.Q.C. Vu, Plastic pollution: Management solutions and research (Hanoi, Vietnam) (2019).

2. T.H. Tran, A review of plastic wastes in the world and in Vietnam. Promoting interventions to reduce plastic wastes (Hoi An, Vietnam, 2019).

3. UNEP. Single-use plastic: A roadmap for sustainability. (2018)

4. R.L. Hotz. The Wall Street Journal (2015)

5. R. Crotti and T. Misrahi. World Economic Forum: (Geneva, Switzerland, 2017).

6. C.A. Lagman, National forum: $4^{\text {th }}$ Sea Dialogue (Hanoi, Vietnam) (2019)

7. C.H. Nguyen, Coastal environmental priorities towards sustainable coastal economic development in Phu Yen province. Directions in environmental protection in socioeconomic development in Phu Yen province (Tuy Hoa, Vietnam, 2019).

8. Ocean Conservancy. Together for Our Ocean: International Coastal Cleanup 2017 Report. 2017 (2017)

9. H.A. Le, T.M.T. Mac, T.B.L Nguyen. Source, collection and processing of plastic wastes in Vietnam. Journal of Environment 10 (2018)

10. Institute of Tourism Development. Scientific foundation and solutions to faciliate sustainable tourism in Vietnam. State-funded reseach project report. Hanoi (2002).

11. Vietinbank Securities. Updated report of Vietnam plastic industry. Hanoi, December (2017)

12. H.V. Tran, Plastic pollution: Management solutions and research (Hanoi, Vietnam) (2019).

13. FAO. State of Food and Agriculture in Asia and the Pacific Region, including Future Prospects and Emerging Issues. Thirty-fourth Session. Paper presented at Regional Conference for Asia and the Pacific (APRC), Nadi, Fiji, 9 April 2018 (2018).

14. Vu T.Q.C., Plastic pollution in coastal regions in Vietnam. National conference: Plastic pollution: Management solutions and research, Hanoi, Vietnam, 8 August 2019.

15. Tran T.H., A review of plastic wastes in the world and in Vietnam. Promoting interventions to reduce plastic wastes, Hoi An, Vietnam, 28 October 2019. 